the weight of a single engine on the Metropolitan Railway. The maximum resistance at twenty miles an hour will be about 2,420 lbs., requiring to overcome it a pneumatic pressure of 2.6 ounces per square inch, and 162-horse-power, assuming the useful effect to be sixty per cent.

A VERY severe thunderstorm passed over London on the evening of July 5. Between eight and nine there came a very brilliant flash of lightning, followed by a deafening peal of thunder. Many people were stunned and in several cases were found quite insensible. Immediately after it was found at Kilburn that the telegraph wires, running from the top of the Queen's Arms to a house about 300 yards higher up the Edgeware Road, were struck by the lightning, and fell in red-hot fragments, varying in length from six inches to an inch, all along the road, a great deal of yellow smoke attending the fall of the wire. In one or two houses windows were broken, and a little girl who was passing through the street had her hair singed and her jacket burnt. The instruments at the office with which the destroyed wires were connected were much agitated, and the telegraph clerk, a young lady, was much stunned.

THE fourth edition of the "Lists of Elevations principally in that portion of the United States West of the Mississippi," edited by Mr. Henry Gannett, and published in connection with Mr. Hayden's Survey, must prove of great value to the geographer and meteorologist. The first edition; published in 1872, contained only thirty-one pages, the present edition contains 164 pages. It contains, among a variety of other matter, profiles of nearly all the railroads in the part of the United States above mentioned. The results given by these profiles have been made to accord, and the heights of several thousands of points on them have been determined with an approach to accuracy. This edition contains also the heights of many thousands of pcints determined approximately by means of the barometer. Elevations of many thousands of mountain-peaks are given, from which very correct ideas of the ruling heights of the principal ranges may be derived. It contains also tables of the slopes of the principal streams of the west, which are of value in studying the important question of irrigation. With these various lists of elevations there is given with this edition a map of the United States, in approximate contours of $\mathbf{I}, 000$ feet of vertical intervals, which, in a measure, embodies all the results of this department. Toward the improvement and ultimate perfection of this map this work is to be mainly directed in future. To express still more clearly the facts brought out by the map, it is the intention of the Survey to make shortly a relief model of the United States, on the bisis of this map.

WE have on several occasions referred to the association known as the Yorkshire Naturalists' Union, composed of a large number of local scientific societies in Yorkshire. This association pub. lishes a useful monthly journal, The Naturatist, intended as a general field club record. We have received the twenty-fourth number of this journal, which, besides several papers on natural history, contains reports of several of the associated societies. From a report of the third meeting of the Union held recently at Wakefield, we notice that the Bradford Scientific Association was admitted to the Union, and that a testimonial, in the shape of a microscope, was presented to Mr. J. M. Barker, late secretary of the West Riding Consolidated Naturalists' Society.

THE additions to the Zoolozical Society's Gardens during the past week include four Common Kingfishers (Alcedo ispida) European, presented by. Mr. J. Lyford; two Horned Lizards (Phrynosoma cornutum) from Texas, presented by Mr. W. A. Bowie; a Sun Bittern (Eurypyga helias), a Sacred Ibis (Geronticus athiopicus), bred in the Gardens ; eight speckled Terrapins (Clemmys guttata), three Red-vented Terrapins (Clemmys rubrivento is), two American Box Tortoises (Terrapcne carinata) from North America, purchased.

\section{THE INFLUENCE OF LIGHT UPON THE DEVELOPMENT OF BACTERIA ${ }^{1}$}

$W^{E}$ have been engaged during the last few months on an investigation into the effect of light upon the development of bacteria in certain of those solutions in which they are usually produced.

We reserve the details for a paper which we hope to submit to the Royal Society in the course of their next session, but wish to state, in the meanwhile, that the first portion of our inquiry has led us to the following conclusions :-

I. That light is inimical to the development of bacteria.

2. That under favourable conditions it may prevent their development.

3. That under less favourable it may not prevent but only retard.

4. That for the full effect of light to be produced direct insolation is necessary.

5. That those conditions which tend to neutralise the action of light are the same which are known to favour processes of fermentation and putrefaction.

6. That the fitness of the solution to serve as a nidus is not destroyed by insolation.

7. That, so far as our investigation has yet gone, it would appear that the germs originally present in the solution are destroyed by direct insolation.

We are still pursuing the inquiry, and have devoted much time to investigating the influence of the refrangibility of the ray, but regret that at present we are not in a position to give any definite conclusions on this point.

We are endeavouring also to trace an analogy between facts which we have observed and certain vital and chemical pro. cesses, in which light is known to play a part, and are extending our observations to other phenomena of fermentation and to microscopic fungi.

That light is not essential for the development of bacteria has been long known, but that it is absolutely inimical to their production has not, so far as we are able to ascertain, been previousiy shown, and we are encouraged, therefore, to lay before the readers of NATURE this statement if our results.

ARThur Downes; T. P. BLUn'T

\section{UNIVERSITY AND EDUCATIONAL INTELLIGENCE}

LONDON.-The following is the list of the new associates of the Royal School of Mines :-Associates in Mining and Metallurgy-C. W. Folkard, A. K. Huntington, E. W. Voelcker; Associates in Mining-E. H. Liveing, W. H. Merritt ; Associates in Metallurgy-A. C. Copeland, J. F. Hogan, C. H. Lemann, W. Leyson, E. T. McCarthy; Associate in Geology-A. R, Sawyer. The Edward Forbes Medal and prize of books was awarded to A. Heilprin; the De la Beche Medal and prize of books to E. W. Voelcker; the Murchison Medal and prize of books to F. G. Mills.

\section{SCIENTIFIC SERIALS}

Fournal de Physigue, June.-On the theory of electrometers, by $M$. Mascart.-On the dynamical theory of gases (continued), by $M$. Violle.-Process for measuring the index of refraction of liquids, by M. De Waha.-Application of the electric current to the study of the spheroidal state of liquids, by M. Hesehus.Temperature and humidity of the air at different heights observed at Upsala during 1875 , by M. Hamberg.-Proceedings of the Physical Society of St. Petersburg.

Archives des Sciences Physiques et Naturelles, June 15.-Study on the variations of transparence of the waters of. Lake Leman, by M. Forel.--On the different modes of crystallisation of water, and the causes of the varied appearances of ice, by M. Pictet. Researches on some niobiferous and tantaliferous minerals, by M. Delafontaine.

Annalen der Physik und Chemie, No. 4, 1877.-Johann Christian. Poggendorff (memoir). - New experiments on the expansion of bodies by heat, by $M$. Glatzel. - On the objections of Clausius to Weber's law, by M. Zöllner.-On normal magnetisation, by M. Petruscheffsky.-On stratification of the electric light in Geissler tubes after insertion of a flame and some other resistances, by M. Holtz. - - On the cohesion of salt solutions, by $M$. 